\title{
PHYSIOLOGICAL AND BIOCHEMICAL ALTERATIONS ON THE STORAGE OF Cedrela fissilis VELLOZO SEEDS
}

\author{
Andressa Vasconcelos Flores ${ }^{1 *}$, Glauciana da Mata Ataíde ${ }^{2}$, Vinícius Oliveira Castro ${ }^{2}$, Eduardo Euclydes de \\ Lima e Borges ${ }^{3}$, Renato Márcio Dias Pereira ${ }^{4}$ \\ 1* Universidade Federal de Santa Catarina, Curitibanos, Santa Catarina, Brazil - andressafloressm@yahoo.com.br \\ ${ }^{2}$ Universidade Federal de São Jão Del-Rei, Sete Lagoas, Minas Gerais, Brazil - glaucianadamata@yahoo.com.br, castrorvo@ymail.com \\ ${ }^{3}$ Universidade Federal de Viçosa, Viçosa, Minas Gerais, Brazil - elborges@ufv.br \\ ${ }^{4}$ Universidade Federal do Rio Grande do Norte, Macaíba, Rio Grande do Norte, Brazil - marcioagron@ufrnet.br
}

Recebido para publicação: 05/05/2016 - Aceito para publicação: 14/12/2017

\begin{abstract}
In order to ensure the ex-situ conservation of a species, knowing the behavior of the seed during storage is necessary, as it is influenced by several factors inherent to the seed and by characteristics of the environment, such as temperature and relative humidity. This study aimed to evaluate the physiological and biochemical alterations on Cedrela fissilis (pink cedar) seeds during storage under different environmental conditions. Seeds were stored at $20^{\circ} \mathrm{C}$ in desiccators containing salts that established the relative humidity of $34 \%, 55 \%, 75 \%$, and $93 \%$. Analysis were performed on fresh seeds (without storage - time zero), which were used as control, and every two months through a period of eight months of storage. At each assessment, the following aspects were quantified: water content; lipid peroxidation; and the activities of catalase and glucose-6-phosphate dehydrogenase. Germination and electrical conductivity tests were analysed. Seed vigor decreased on humidity at $20{ }^{\circ} \mathrm{C}$. It correlated mainly with decrease of glucose-6-phosphate dehydrogenase activity and increase of lipid peroxidation.

Keywords: Pink cedar, germination, vigor, enzymes, lipids.
\end{abstract}

\section{Resumo}

Alterações fisiológicas e bioquímicas durante o armazenamento de sementes de Cedrela fissilis Vellozo. Para garantir a conservação ex-situ de uma espécie, é necessário conhecer o comportamento das sementes durante o armazenamento, visto que este é influenciado por vários fatores inerentes à semente e às características do ambiente, tais como temperatura e umidade relativa. Este estudo teve como objetivo avaliar as alterações fisiológicas e bioquímicas em sementes de Cedrela fissilis (cedro rosa) durante o armazenamento sob diferentes condições ambientais. As sementes foram armazenadas a $20^{\circ} \mathrm{C}$ em dessecadores contendo sais que estabeleceram as umidades relativas do ar de $34 \%, 55 \%, 75 \%$ e $93 \%$. As análises foram realizadas em sementes frescas (sem armazenamento - tempo zero), usadas como controle, e a cada dois meses durante um período de oito meses de armazenamento. Em cada avaliação, foram quantificados: teor de água; peroxidação de lípidos; e as atividades das enzimas catalase e glicose-6-fosfato desidrogenase. Também, foi analisada a germinação e condutividade elétrica das sementes. $\mathrm{O}$ vigor das sementes diminuiu em todas as umidades a $20{ }^{\circ} \mathrm{C}$, correlacionando-se, principalmente, com a diminuição na atividade de glicose-6-fosfato desidrogenase e com o aumento na peroxidação lipídica.

Palavras-chave: Cedro rosa, germinação, vigor, enzimas, lipídios.

\section{INTRODUCTION}

Preserving the biodiversity of tropical ecosystems has been one of humanity's main concerns in the last decades. Due to forestry devastation that aims to attend the demands of countries and the agricultural expansion, the genetic potential of several native species has been compromised. This situation causes their extinction and risks the ecosystems survival.

Fragmentation of the ecosystem resulted in reduction on the number of habitats available for fauna and flora species. Therefore, it increased isolation of species and enabled the extinction of important specimens. Several species from the Atlantic Forest biome are in danger of extinction. The Ordinance 443 of the Ministry of Environment published the "Official List of Species from the Brazilian Flora in Danger of Extinction" (BRASIL, 2014). Based on it, studies aiming to restitute the species of this list and their preservation and sustainable management became indispensable. In this context, environmental policies and national and international researches have been directed to preserve these species.

FLORESTA, Curitiba, PR, v. 48, n. 1, p. 01-08, jan./mar. 2018.

Flores, A.V. et al.

ISSN eletrônico 1982-4688

DOI: $10.5380 /$ rf.v48 i1.46601 
Among the arboreal species in the list with reduced genetic variability, Cedrela fissilis Vellozo, also known as pink cedar, is highlighted. This species is native of the Atlantic Forest, and mostly found in Rio Grande do Sul and Minas Gerais, Brazil (LORENZI, 2009). It is used usually in joinery, shipbuilding, and aircraft. These multiple uses make this wood one of the most economically important species in Brazil.

In the last years, the production of seeds of forest species became relevant in programs for forest reposition, reforestation and restoration of damaged areas, and urban afforestation, among other activities. Studies regarding the physiological processes of seeds are the starting point for use and sustainable exploration of native species. Physiological, genetic and physical attributes are preponderant factors for the success of programs.

The seeds are submitted to degenerative changes of biochemical and physiological order over time, which causes the deterioration of cell structures and, posteriorly, death (KAPOOR et al., 2011). The deterioration process is a barrier on the management and conservation of the species in germplasm banks (KUMAR et al., 2011). Researches regarding the storage of seeds have been increasing over the years, especially those in relation to environmental conditions and packings. In order to develop these studies, environmental conditions of the storage place are established, and the results are observed. The correlations between quality loss of the seeds and physiological and biochemical conditions do not prevail. Such information, besides being relevant for the basic research, is essential for better understanding of the ecological processes of plant establishment, succession, and regeneration by the researcher community, since it is a basic tool to preserve the species.

In this context, the storage of seeds under high relative humidity conditions can increase the speed of seed deterioration, which may cause losses for the viability and conservation of germplasm. Considering the relevance of studies and the lack of information regarding forestry species, this research aimed to evaluate the physiological and biochemical alterations that occur during storage, and the loss of viability in Cedrela fissilis seeds under different relative humidity conditions.

\section{MATERIAL AND METHODS}

\section{Vegetal material and experiment location}

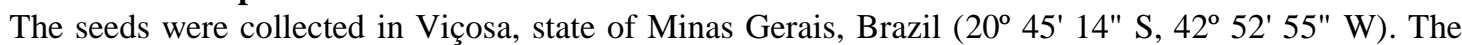
experiments were conducted in the Laboratory of Forest Seeds of the Department of Forestry, Federal University of Viçosa (Laboratório de Análise de Sementes Florestais do Departamento de Engenharia Florestal, Universidade Federal de Viçosa) from September 2011 to March 2013.

Collected fruits were drought under sun light until their opening, and seeds containing approximately $8 \%$ of water content were allocated into plastic packings inside cardboards drums $(25 \times 22.5 \mathrm{~cm})$ at $20^{\circ} \mathrm{C}$. During the benefitting, immature, deteriorated and damaged seeds were eliminated.

\section{Analysis and Quantifications}

The seeds were stocked in desiccants at $20^{\circ} \mathrm{C}$ under different relative humidity (Table 1). The analyses were performed on freshly harvested seeds (without storage - time zero), which were used as control, and every two months during eight months of storage.

Table 1. Saturated solutions of salts and their respective relative humidity $(\mathrm{RH})$ during the storage of Cedrela fissilis seeds at $20^{\circ} \mathrm{C}$.

Tabela 1. Soluções saturadas de sais e respectivas umidades relativas (RH) durante o armazenamento de sementes de Cedrela fissilis a $20^{\circ} \mathrm{C}$.

\begin{tabular}{clc}
\hline Temperature $\left({ }^{\circ} \mathbf{C}\right)$ & \multicolumn{1}{c}{ Salts } & RH $(\%)$ \\
\hline \multirow{2}{*}{20} & Magnesium chloride $\left(\mathrm{MgCl}_{2} \cdot 6 \mathrm{H}_{2} \mathrm{O}\right)$ & 34 \\
& Calcium nitrate $\left(\mathrm{Ca}\left(\mathrm{NO}_{3}\right)_{2}\right)$ & 55 \\
& Sodium chloride $(\mathrm{NaCl})$ & 75 \\
& Monophosphate Ammonium $\left(\mathrm{NH}_{4} \mathrm{H}_{2} \mathrm{PO}_{4}\right)$ & 93 \\
\hline
\end{tabular}

Source: ROCKLAND et al. (1960).

During each evaluation, the water content was quantified, and germination and electric conductivity tests were performed. The lipid peroxidation and activities of catalase and glucose 6-phosphate dehydrogenase were also determined. Water content was determined by applying the greenhouse method at $105 \pm 3{ }^{\circ} \mathrm{C}$ (humid base) for 
24 hours (BRASIL, 2009). Three repetitions were made, each containing 30 seeds per repetition. The results were expressed in percentage.

To analyze germination, the seeds were cultivated in petri dishes of 9 centimeters of diameter, double lined with germitest filter paper, and moistened with distilled water. The plates were kept in a germinator at $25^{\circ} \mathrm{C}$, under constant light, provided by four fluorescent lamps of $20 \mathrm{~W}$ of daylight type, during 10 days. The germination was determined by the diary counting of the seeds that issued radicle. The results were expressed in average percentage. In order to calculate the Speed Germination Index (SGI), we used the formula: SGI $=\sum\left(\frac{n i}{t i}\right)$; in which: $\mathrm{n}_{\mathrm{i}}$ is the number of seeds per day and $\mathrm{t}_{\mathrm{i}}$ is the time (in days).

In order to compare the membrane integrity during the storage, samples of 50 seeds were allocated in an erlenmeyer with $70 \mathrm{~mL}$ of distillated water at $20^{\circ} \mathrm{C}$ for 24 hours. The electric conductivity of the leachates was determined by using a MICRONAL conductivimeter, B 330 model, electrode with constant 1.0.

The lipid peroxidation was evaluated by determining the TBA index, thiobarbituric acid (LEHNER et al., 2008). Seeds homogenized with distilled water and hydrochloric acid were used. The samples were retrieved periodically and combined with TBA and glacial acetic acid solutions. Based on that, the spectrophotometry of the lipid peroxidation at $560 \mathrm{~nm}$ was determined.

The crude enzyme extract used to determine the catalase activity (CAT) was obtained by macerating $0,1 \mathrm{~g}$ of seeds without tegument, stocked in ice, and adding 2,0 mL of the following homogenization tool: $0.1 \mathrm{M}$ potassium phosphate buffer, pH 6,8, ethylenediaminetetraacetic acid (EDTA) 0,1 mM, phenylmethylsulfonyl fluoride (PMSF) $1 \mathrm{mM}$ and polyvinylpolypyrrolidone (PVPP) 1\% (w / v) (PEIXOTO et al., 1999). Then, the extract was centrifuged at 15.000 for 15 minutes at $4{ }^{\circ} \mathrm{C}$, which resulted in the crude enzyme extract. The catalase activity was determined by adding $100100 \mu \mathrm{L}$ of the crude enzyme extract at 2,9 $\mathrm{mL}$ of a reaction tool constituted of $50 \mathrm{mM}$ potassium phosphate buffer, $\mathrm{pH} 7,0$ and $\mathrm{H}_{2} \mathrm{O}_{2} 12,5 \mathrm{mM}$. The decrease in absorbance at $240 \mathrm{~nm}$ and $25^{\circ} \mathrm{C}$ was measured during the first minute of reaction. The CAT activity was determined based on the slope of the line after the beginning of the reaction. The enzyme activity was calculated by using the molar extinction coefficient of $36 \mathrm{M} \mathrm{C}-1$, and the result was expressed in $\mu$ molmin $^{-1} \mu \mathrm{g}^{-1}$ protein. Three tripled repetitions were performed.

The crude enzyme extract used to determine the enzyme activity of glucose-6-phosphate dehydrogenase was obtained by following the method described by Ataíde et al. (2016), with adaptations. Samples of $0,1 \mathrm{~g}$ seeds without tegument were crushed on ice; then $2,0 \mathrm{~mL}$ of the following homogenization tool was added: $2.0 \mathrm{~mL}$ extraction means of Tris- $\mathrm{HCl} 50 \mathrm{mM}, \mathrm{pH} \mathrm{7.5}$. The extract was centrifuged at $15.000 \mathrm{xg}$ for 15 minutes at $4{ }^{\circ} \mathrm{C}$, which resulted in the crude enzyme extract. The glucose-6-phosphate dehydrogenase was determined by adding $200 \mu \mathrm{L}$ of the enzyme extract at $2,8 \mathrm{~mL}$ from a reaction tool constituted of $2,6 \mathrm{~mL}$ of Tris- $\mathrm{HCl}$ buffer $\mathrm{pH} 7.5$ $62.5 \mathrm{mM} \mathrm{MgCl} 2+6,25 \mathrm{mM}$, summed $100 \mu \mathrm{L}$ of NADP $10 \mathrm{mM}$ and $100 \mu \mathrm{L}$ of G-6-P. The increase of absorbance at $340 \mathrm{~nm}$ and $30^{\circ} \mathrm{C}$ was measured for 30 minutes of reaction. The G-6-P-D activity was determined based on the slope after the start of the reaction. The enzyme activity was calculated by using the molar extinction coefficient of $6,22 \mathrm{mmol} \mathrm{cm}^{-1}$, and the result was expressed in molmin ${ }^{-1} \mu \mathrm{g}^{-1}$ protein. Three tripled repetitions were performed. The protein content was determined by the Bradford method, using the pattern curve constituted of bovine serum albumin (BSA).

\section{Experimental Delineation and Statistical Analysis}

The delineation was completely randomized. Data were submitted to the Kolmogorov-Smirnov test to verify the normality. Then, we proceeded with the variance analysis. Linear regression equations were adjusted according to time of storage under different environmental conditions. The statistical package used was Statistica 8.0.

\section{RESULTS}

The seeds presented initial water content of $8.27 \%$. On all treatments, the seeds absorbed water during the storage (Figure 1). Such absorption was more prominent under the relative humidity of $93 \%$, in which the water content increased continuously, and reached $31.55 \%$ after six months of storage. The differences of water content at 34 and $55 \%$ of relative humidity were minimum. There was little increase and stabilization for four months. At $75 \%$ humidity, increase was observed especially during the four initial months, followed by balance.

FLORESTA, Curitiba, PR, v. 48, n. 1, p. 01-08, jan./mar. 2018

Flores, A.V et al.

ISSN eletrônico 1982-4688

DOI: $10.5380 /$ rf.v48 i1.46601 


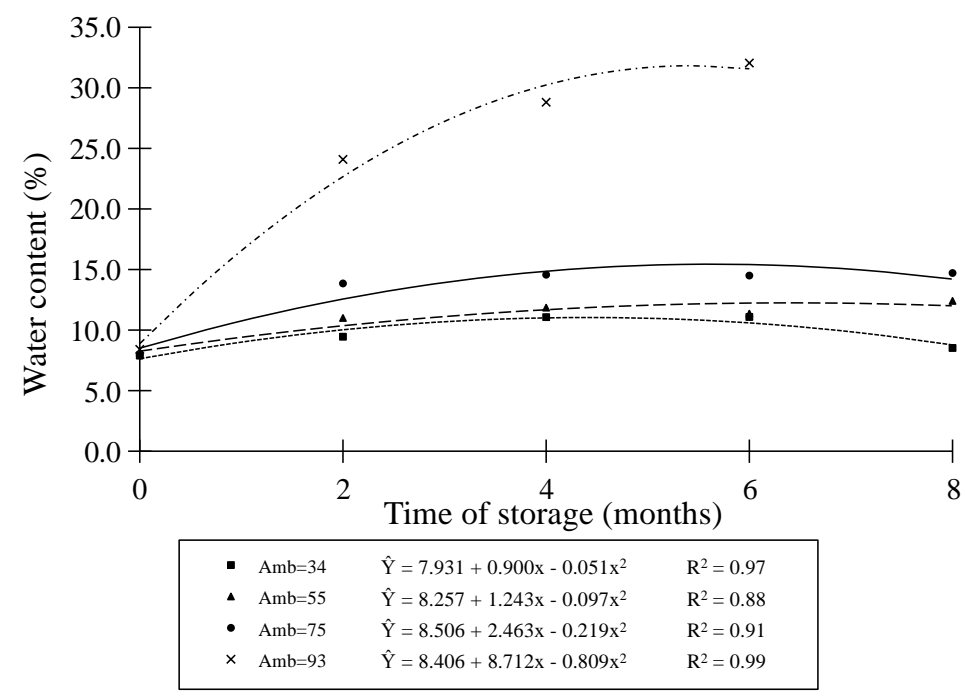

Figure 1. Water content in Cedrela fissilis seeds during storage at $20{ }^{\circ} \mathrm{C}$ and relative humidity at 34 , 55,75 and $93 \%$.

Figura 1. Teor de água de sementes de Cedrela fissilis durante o armazenamento a $20^{\circ} \mathrm{C}$ nas umidades relativas de $34,55,75$ e $93 \%$.

The germination percentage of C. fissilis seeds (94\% initially) presented distinct behavior regarding the storage environments (Figure 2a). On treatments of 93 and $75 \%$ of humidity, the decrease in germination was accentuated, and the death of the seeds was observed at $93 \%$. At $75 \%$ humidity, it was verified after eight months. At relative humidity of 34 and $55 \%$, a smaller loss of germination potential was verified, especially in the first. 81.1 and $52.4 \%$ of viability, respectively, were observed by the end of the period. These results prove that the RH is a relevant factor in maintaining the physiological quality of $C$. fissilis seeds during storage.

The alterations on the SGI through time were similar to those observed for germination, with a prominent decrease on the seeds kept in the humidity of $93 \%$, followed by $75 \%$ (Figure $2 \mathrm{~b}$ ). The SGI values for seeds kept at 34 and $55 \%$ of RH were similar, different from what occurred in the germination. During a rigorous evaluation of the seeds quality, a reduction on seed vigor under all relative humidity conditions was perceived. It was more accentuated in higher $\mathrm{RH}$.
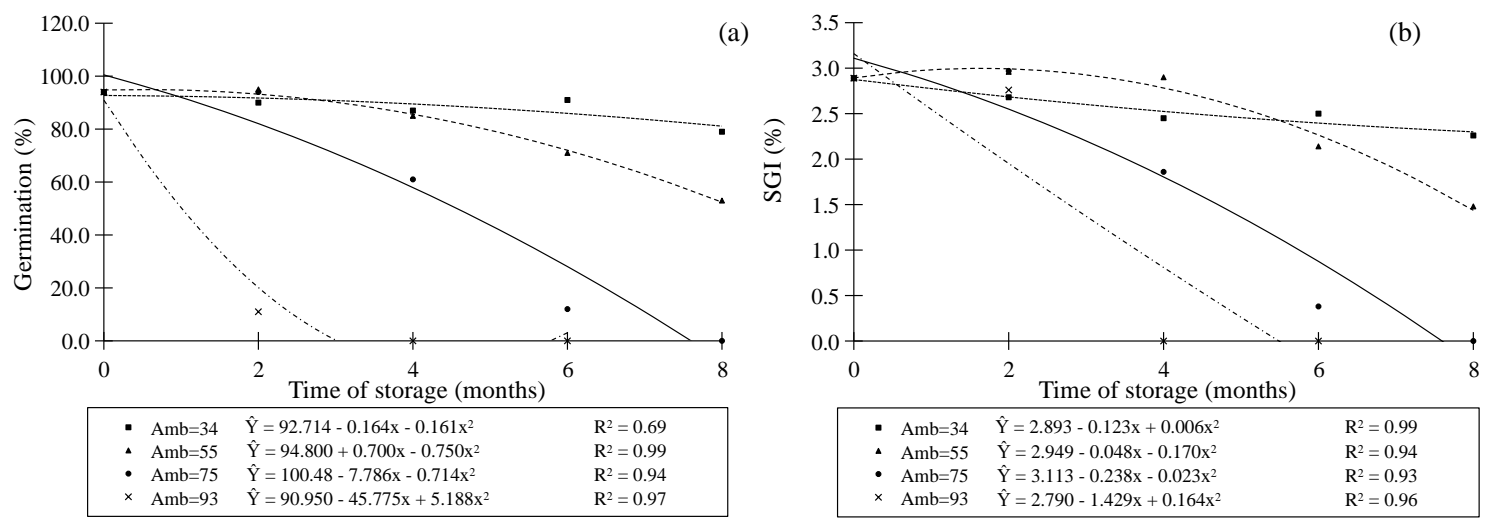

Figure 2. Germination (a) and Speed Germination Index (SGI) (b) of Cedrela fissilis seeds during storage at $20^{\circ} \mathrm{C}$ and relative humidity at $34,55,75$ and $93 \%$.

Figura 2. Germinação (a) e Índice de Velocidade de Germinação (IVG) (b) de sementes de Cedrela fissilis durante o armazenamento a $20^{\circ} \mathrm{C}$ nas umidades relativas de $34,55,75$ e $93 \%$.

A tendency of increasing of electric conductivity was verified at all storage conditions (Figure 3a). Greater intensity was verified after four months, especially at 93\% humidity. The conductivities of the seeds storage at 75, 55 and $34 \%$ were similar during six months of storage. However, there was a slight difference in the 
last evaluation (eight months of storage), when there was increase as the humidity increased. The conductivity was lower at $34 \%$.

The lipid peroxidation increased continuously at 34, 55 and $75 \%$ of relative humidity, and the values were similar in the three conditions (Figure 3b). At $93 \%$ humidity, lipid peroxidation remained almost constant during the storage period, with low variation.
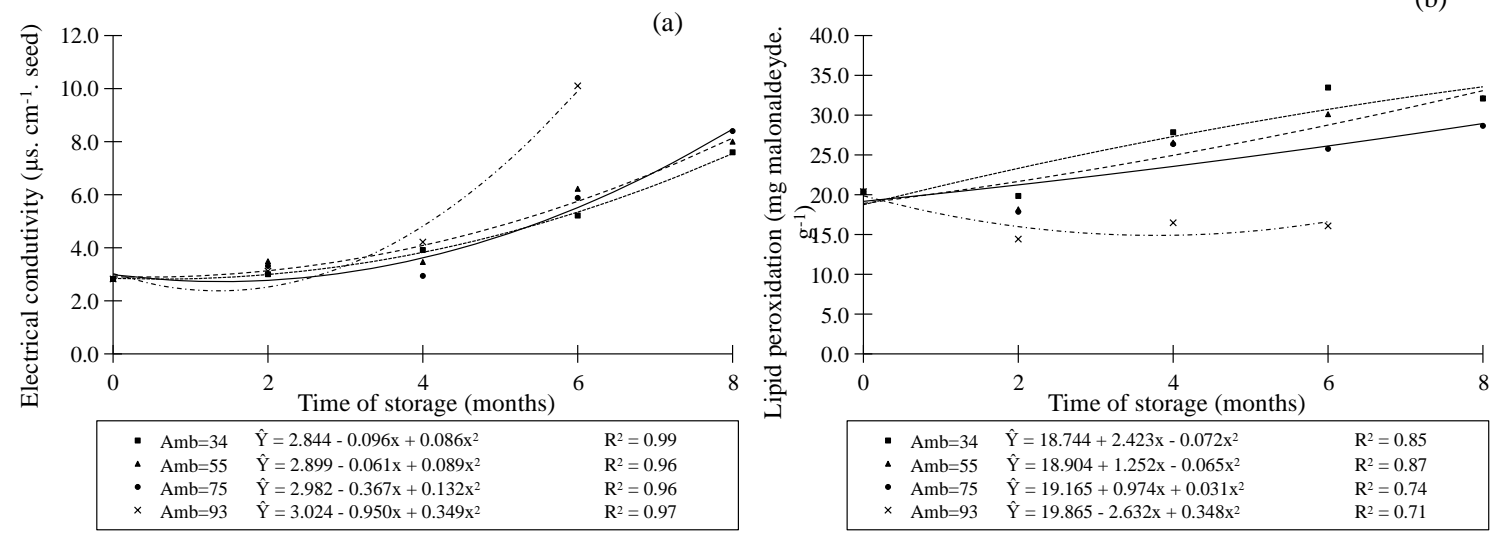

Figure 3. Electric conductivity (a) and lipid peroxidation (b) in Cedrela fissilis seeds during storage at $20{ }^{\circ} \mathrm{C}$ and relative humidity at $34,55,75$ and $93 \%$.

Figura 3. Condutividade elétrica (a) e peroxidação de lipídios (b) de sementes de Cedrela fissilis durante o armazenamento a $20^{\circ} \mathrm{C}$ nas umidades relativas de $34,55,75$ e $93 \%$.

The catalase activity increased on seeds kept at the relative humidity of $93 \%$ for two months. Then, they decreased continuously (Figure 4a). At 34, 55 and 75\% humidity, the catalase activity varied little when compared to the environments and storage periods.
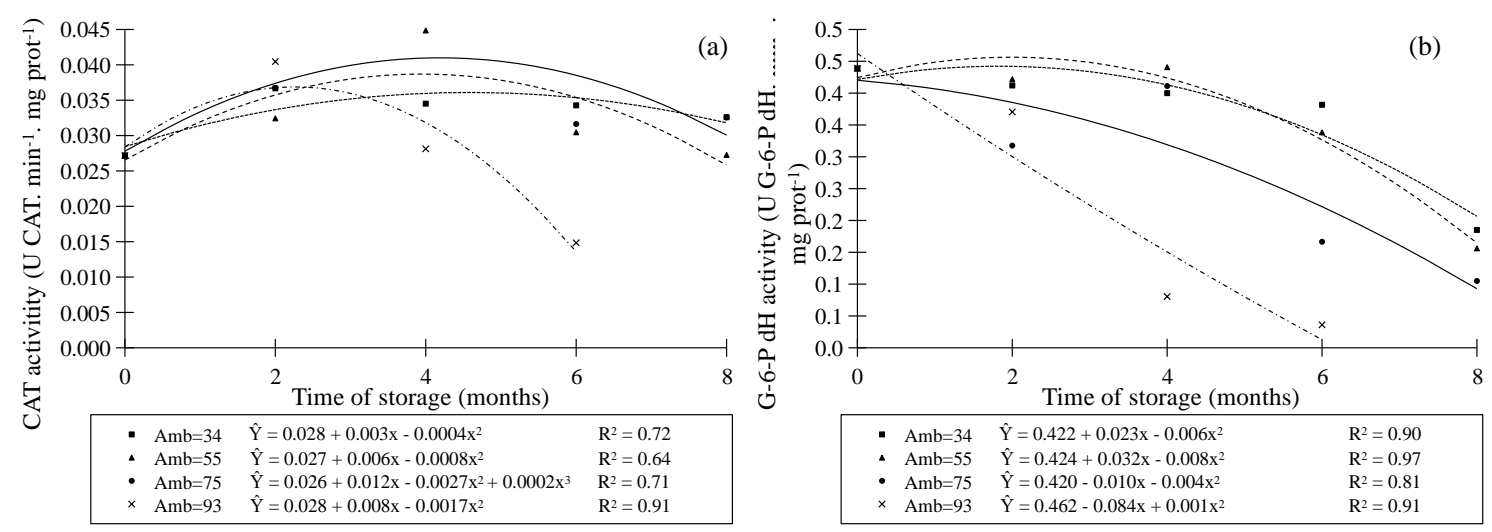

Figure 4. Specific catalase activity (CAT) (a) and glucose 6-phosphate dehydrogenase (G-6-P dH) (b) in Cedrela fissilis seeds during storage at $20^{\circ} \mathrm{C}$ and relative humidity at $34,55,75$ and $93 \%$.

Figura 4. Atividade específica de catalase (CAT) (a) e glicose-6-fosfato desidrogenase (G-6-P dH) (b) de sementes de Cedrela fissilis durante o armazenamento a $20^{\circ} \mathrm{C}$ nas umidades relativas de $34,55,75$ e $93 \%$.

According to data provided by Figure 4b, the activity of glucose 6-phosphate dehydrogenase decreased under all relative humidity conditions, and it is more accentuated at 75 and $93 \%$. It is perceived that the vigor (Figure 2b) and the enzyme activity remain constant during the first four months at 34 and 55\% $\mathrm{RH}$; then they decrease more prominently at $55 \%$, as the vigor. Therefore, the mono-phosphate pentose route takes an important role on the maintenance of seeds vigor, especially because this metabolic route produces pentose for amino acid synthesis, intermediates of glycolysis, such as glyceraldehyde-3-phosphate, and controls the ATP production by glycolysis and the NADPH re-oxidation, extremely important on germination reactions.

FLORESTA, Curitiba, PR, v. 48, n. 1, p. 01-08, jan./mar. 2018.

Flores, A.V. et al.

ISSN eletrônico 1982-4688 


\section{DISCUSSION}

The seed, as hygroscopic, varies considerably regarding the humidity content based on the atmospheric humidity, and it interferes on the metabolic activities (ATAÍDE et al., 2015). We suppose that the seeds reach values of hygroscopic balance in a shorter period on lower relative humidity, establishing it beforehand. Borges et al. (2009) observed similar results for Anadenanthera peregrina seeds. The balance values of these seeds were obtained in 15 days for environments at 34, 55 and $75 \%$, but it was reached only in 39 days at $93 \%$ RH, with higher water content.

The increase of relative humidity associated to $20^{\circ} \mathrm{C}$ would stimulate the metabolic activity of the seeds, due to the increase of the $\mathrm{CO}_{2}$ content inside the recipients, which might be one of the causes for the viability reduction or death of the seeds. Apparently, by reaching a certain water content (in this case, $75 \% \mathrm{RH}$ ), the metabolism is clearly accelerated as the viability decreases. In long term, the water content reached by the seeds at $34 \% \mathrm{RH}$ also results in a progressive quality loss.

According to Martins and Lago (2008), the conservation of C. fissilis seeds is favored by lower humidity levels at 10 and $20^{\circ} \mathrm{C}$. The stock of seeds from species in controlled environment $\left(5^{\circ} \mathrm{C}\right.$ and $\left.60 \% \mathrm{RH}\right)$ was efficient to maintain the viability for twelve months, while, in a non-controlled environment, the maintenance of the physiological quality is reduced. In this context, Medeiros and Eira (2006) recommend a preliminary drying of seeds until the hygroscopic balance is reached, period when they must be stocked.

The decrease of the SGI during the seeds storage proved that the vigor loss precedes the viability loss, and is an important indicator on seeds evaluation (SILVA et al., 2011). Especially regarding the $C$. fissilis batch separation, the SGI was efficient to demonstrate the vigor differences, behavior that was not identified by the germination test most of the time. When the deterioration of the seeds increased, the speed of the germination reduced. These results were observed for Melanoxylon brauna (BORGES et al., 2015) and Tabernae montana (MORAES et al., 2016).

The electric conductivity test was directly related to the cell membranes integrity, since the levels reorganization of the membrane and the reparation of damages are higher on seeds with greater vigor (DALANHOL et al., 2014), as those kept at 34\% of relative humidity. This test has been efficient to evaluate the membrane permeability during seed deterioration on arborous species (ORTIZ et al., 2015).

By comparing the SGI to the electric conductivity, we verified that the first was more effective to indicate the quality loss of seeds. Even though the breakdown of the system is an important step on the seed deterioration process (MARCOS FILHO, 2015), the electric conductivity test was not efficient to detect differences among the vigors of $C$. fissilis at relative humidity of 34,55 and $57 \%$. Therefore, the electric conductivity test is adequate to detect elevated levels of deterioration, and it is less sensitive to perceive lower or intermediary levels during the storage.

The increase on the level of malonaldehyde (a product of the lipid peroxidation) in the seeds was considered as one of the main results of seed deterioration (CAKMAK et al., 2010). The lipid peroxidation in seeds compromises its activity when it occurs in a cell membrane level. It affects its semi-permeability and allows the leakage of solutes into the medium (ATAÍDE et al., 2016), which justifies the viability loss at lower relative humidity. At $93 \% \mathrm{RH}$, the alteration on the peroxidation may relate to the death of the seed, since the germination was reduced to $20 \%$ in two months. The increase of $\mathrm{CO}_{2}$ possibly inhibited the operation of electron transport chain and oxidative phosphorylation, which caused the death of the seeds. However, it did not avoid the production of reactive substances (SROs). Consequently, the cell membranes permeability increased. Such effect was more evident at $93 \%$ humidity, since the variations of peroxidation and conductivity were smaller at other environments.

Murthy et al. (2003) stated that the increase of the water content on Vigna radiate seeds inhibited the lipid peroxidation. Thus, the water could act as a buffer between the oxidation and synthesis of target molecules and free radicals, suppressing the autocatalytic chain reaction peroxidation. The lipid peroxidation was similar in environments at 35 and $55 \%$ of relative humidity, and similar to the SGI for these environments. The reduction of vigor was accentuated at $75 \% \mathrm{RH}$, even though the alterations on the conductivity were not evident. Such conductivity value is sufficient to indicate the quality loss of seeds, reducing its precision as the environments become more appropriated for preservation. Therefore, it is possible to state that the peroxidation is related to the quality loss of $C$. fissilis stocked, as observed by Borges et al. (2015).

The increase on relative humidity at $20{ }^{\circ} \mathrm{C}$ probably stimulated the breathing and, consequently, increased the reactive oxygen species (SRO) production, with no antioxidant system acting effectively. The Km of catalase for the hydrogen peroxide is high, which indicates little affin ity. Therefore, the quantity of SRO produced was not sufficient to stimulate the full activity of the enzyme. Thus, it allowed the values of reactive substances to act on basic components of metabolism as the proteins and carbohydrates. 
Kibinza et al. (2011) affirm that catalase is a key enzyme on the loss of vigor in seeds during deterioration, showing a decrease on the enzyme at the level of gene expression, protein content and protein affinity. The catalase activity decreased during the aging of Pterogyne nitens seeds (ATAÍDE et al., 2012). More accentuated decrease was stated when the viability of seeds was under 60\% (DEMIRKAYA et al., 2010).

\section{CONCLUSIONS}

- At $20^{\circ} \mathrm{C}$, all tested levels of relative humidity decreased the Cedrela fissilis seeds germination.

- The glucose 6-phosphate dehydrogenase activity and lipid peroxidation indicate the quality loss of stored seeds.

\section{REFERENCES}

ATAÍDE, G. M.; BORGES, E. E. L.; FLORES, A. V. Enzymatic activity in braúna seeds subjected to thermal stress. Ciência Rural, v. 46, n. 6, p. 1044-1049, 2016.

ATAÍDE, G. M.; BORGES, E. E. L.; FLORES, A.V.; CASTRO, R. V. O. Avaliação preliminar da embebição de sementes de jacarandá-da-bahia. Pesquisa Florestal Brasileira, v. 34, n. 78, p. 133-139, 2015.

ATAÍDE, G. M.; BORGES, E. E. L.; LEITE FILHO, A. T. Alterações fisiológicas e biométricas em sementes de Melanoxylon brauna Schott durante a germinação em diferentes temperaturas. Revista Árvore, v. 40, n. 1, p. 6170, 2016.

ATAÍDE, G. M.; FLORES, A. V.; BORGES, E. E. L.; RESENDE, R. T. Adequação da metodologia do teste de condutividade elétrica para sementes de Pterogyne nitens Tull. Revista Brasileira de Ciências Agrárias, v. 7, n. 4, p. 635-640, 2012.

BORGES, S.; BORGES, E. E. L.; CORREA, P. C.; BRUNE, A. Equilíbrio higroscópico e viabilidade de sementes de angico-vermelho (Anadenanthera peregrina (L.) Speng) em diferentes condições ambientais de armazenamento. Scientia Forestalis, v. 37, n. 84, p. 475-481, 2009.

BORGES, E. E. L.; FLORES, A. V.; ATAIDE, G. M.; MATOS, A. C. B. Alterações fisiológicas e atividade enzimática em sementes armazenadas de Melanoxylon brauna Schott. CERNE, v. 21, n. 1, p. 75-81, 2015.

BRASIL. Ministério da Agricultura. Regras para análise de sementes. Brasília: Secretaria Nacional de Defesa Agropecuária, 2009. 399 p.

BRASIL. Ministério do Meio Ambiente. Portaria MMA no 443, de 17 de dezembro de 2014. Lista Nacional Oficial de Espécies da Flora Ameaçadas de Extinção. Brasília: MMA, 2014. 25 p.

CAKMAK, O. A.; GULERAY, A.; SUNAR, S. Natural aging-related biochemical changes in alfalfa (Medicago Sativa L.) seeds stored for 42 years. International Research Journal of Plant Science, v. 1, n. 1, p. 01-06, 2010.

DALANHOL, S. J.; REZENDE, E. H.; ABREU, D. C. A.; NOGUEIRA, A. C. Teste de condutividade elétrica em sementes de Bowdichia virgilioides Kunth. Floresta e Ambiente, v. 21, n. 1, p. 69-77, 2014.

DEMIRKAYA, M.; DIETZ, K. J.; SIVRITEPE, H. O. Changes in antioxidant enzymes during ageing of onion seeds. Notulae Botanicae Horti Agrobotanici, v. 38, n. 1, p. 49-52, 2010.

KAPOOR, N.; ARYA, A.; SIDDIQUI, M. A.; KUMAR, H.; AMIR, A. Physiological and biochemical changes during seed deterioration in aged seeds of rice (Oryza sativa L.). American Journal of Plant Physiology, v. 6, n. 1, p. 28-35, 2011.

KIBIZA, S.; BAZIN, J.; BAILLY, C.; FARRANT, J. M.; CORBINEAU, F.; EL-MAAROUF-BOUTEAU, H. Catalase is a key enzyme in seed recovery form ageing during priming. Plant Science, v. 181, n. 1, p. 309-315, 2011.

KUMAR, B.; VERMA, S. K.; SINGH, H. P. Effect of temperature on seed germination parameters in Kalmegh (Andrographis paniculata Wall. ex Nees.). Industrial Crops and Products, v. 34, n. 1, p. 1241-1244, 2011.

LEHNER, A.; MAMADOU, N.; POELS, P.; CÔME, D.; BAILlY, C.; CORBINEAU, F. Changes in soluble carbohydrates, lipid peroxidation and antioxidant enzyme activities in the embryo during ageing in wheat grains. Journal of Cereal Sciences, v. 47, p. 555- 565, 2008.

FLORESTA, Curitiba, PR, v. 48, n. 1, p. 01-08, jan./mar. 2018.

Flores, A.V. et al.

ISSN eletrônico 1982-4688

DOI: $10.5380 /$ rf.v48 i1.46601 
LORENZI, H. Árvores Brasileiras. Nova Odessa: Instituto Plantarum, 2009. 384 p.

MARCOS FILHO, J. Seed vigor testing: an overview of the past, present and future perspective. Scientia Agricola, v. 72, n. 4, p. 363 -374, 2015.

MARTINS, L.; LAGO, A. A. Conservação de semente de Cedrela fissilis: teor de água da semente e temperatura do ambiente. Revista Brasileira de Sementes, v. 30, n. 1, p. 161-167, 2008.

MEDEIROS, A. C. S.; EIRA, M. T. S. Comportamento fisiológico, secagem e armazenamento de sementes florestais nativas. Colombo: Circular Técnica 127, EMBRAPA Florestas, 2006. 13 p.

MORAES, E.; LOPES, J. C.; FARIAS, C. C. M.; MACIEL, K. S. Qualidade fisiológica de sementes de Tabernaemontana fuchsiaefolia A. DC em função do teste de envelhecimento acelerado. Ciência Florestal, v. 26, n. 1, p. 213-223, 2016.

MURTHY, U. M. N.; KUMAR, P. P.; SUN, W. Q. Mechanisms of seed ageing under different storage conditions for Vigna radiata (L.) Wilczek: lipid peroxidation, sugar hydrolysis, Maillard reactions and their relationship to glass state transition. Journal of Experimental Botany, v. 54, n. 384, p. 1057-1067, 2003.

ORTIZ, T. A.; MORITZ, A.; TAKAHASHI, L. S. A.; URBANO, M. R. Tests for evaluating the physiological quality of pitaya seeds. Semina: Ciências Agrárias, v. 36, n. 6, suplemento 2, p. 4047-4058, 2015.

PEIXOTO, P. H. P.; CAMBRAIA, J.; SANT'ANNA, R.; MOSQUIN, P. R.; MOREIRA, M. A. Aluminium effects on lipid peroxidation and on the activities of enzymes of oxidative metabolism in sorghum. Revista Brasileira de Fisiologia Vegetal, v. 11, n. 3, p. 137-143, 1999.

ROCKLAND, L. B. Saturated salt solutions for static control of relative humidity between $5^{\circ} \mathrm{C}$ and $40^{\circ} \mathrm{C}$. Analytical Chemistry, v. 32, n. 1, p. 1375-1376, 1960.

SILVA, D. G.; CARVALHO, M. L. M.; NERY, M. C.; OLIVEIRA, L. M.; CALDEIRA, C. M. Alterações fisiológicas e bioquímicas durante o armazenamento de sementes de Tabebuia serratifolia. Cerne, v. 17, n. 1, p. 17, 2011. 